SAD / JSR

Sosyoloji Araştırmaları Dergisi / Journal of Sociological Research

Cilt / Volume 24 Say1 / Number 2 (Nisan / April 2021) : (349-378)
Araştırma Makelesi / Research Article

Geliş Tarihi / Submited: 06.05.2020

Kabul Tarihi / Accepted: 23.11.2020

\title{
GAY MEN'S HOME-MAKING AS AFFECTIVE PRACTICE IN TURKEY: THE PURSUIT OF SAFETY AND COMFORT
}

\section{Haktan URAL ${ }^{1}$}

\section{ABSTRACT}

The geographies of home are discerned as having a particular significance in the lives of gay men. The individual homes of lesbians and gay men are amenable to affirming non-heterosexual identities and subverting the cultural norms of heterosexual family life. This study contributes to understanding this construction of lesbian/gay identity at home. Drawing on gay men's everyday experiences within Turkey's cultural context, I deal with home as a spatial domain laden with diverse meanings and affective registers. I suggest that Turkey's cultural context structures gay men's habitus and informs their knowledge of possible actions that are available to them. In this discursive terrain, they attribute specific meanings of safety and autonomy to their homes. However, these meaning-making practices should not be reduced to an experience of closeting, as gay men's domestic life opens up a space of comfort for gay identities. Insofar as gay men can re-inscribe their homes as sites for the comfort of gay identities, these homes seamlessly become a performative domain. Within them, the men's situated activities pave the way for creation and affirmation of gay identities, in both individual and collective ways. Therefore, I suggest that gay men's affective dispositions (namely safety and comfort) arise out of their relations with people, objects and places, and lead to restructuring their habitus in a way so as to validate their gay identities in domestic life. Yet this is an unfinished project and needs to be renegotiated to ensure gay men's safety and comfort in their everyday lives.

Keywords: Geographies of Sexualities, Gay, Home, Affective Practice, Habitus

${ }^{1}$ Dr. Öğr. Üyesi, Ankara Üniversitesi Dil ve Tarih-Coğrafya Fakültesi, Sosyoloji Bölümü

\footnotetext{
$\mathrm{SAD} / \mathrm{JSR}$

Cilt / Volume 24 Sayı / Number 2
} 


\section{DUYGULANIMSAL BİR PRATIK OLARAK YUVA KURMA: TÜRKİYE'DE GEY ERKEKLERİN GÜVENLİK VE KONFOR ARAYIŞLARI}

\section{ÖZET}

Bu çalışma lezbiyen/gey kimliğinin inşasında ev mekanının oynadığı rolü konu etmektedir. Ev yaşamının mekânsal dinamiklerinin heteroseksüel aile yaşamının kültürel normları ve heteroseksüel olmayan kimliklerin icrası ile ilişkisini incelemektedir. Kendisini eşcinsel olarak tanımlayan erkeklerin gündelik yaşam deneyimlerine dayanarak, kültürel bir kurgu olan yuva kavramının hangi duygulanımsal anlamlarla deneyimlendiği mercek altına alınmaktadır. Buradan hareketle, heteroseksüel olmayan cinsellikleri tertip eden normatif söylemlerin eşcinsel erkekler için pratik bilgisi üreten bir gey habitusunu devreye soktuğu ileri sürülmektedir. Bu bilgi şeması evsel yaşamı özerklik, güvenlik ve konfor eksenlerinin kesişiminde işaretler. Ancak bu anlamların gey kimliğini tecrit eden bir dolap (closet) deneyimine tercüme edilmediği ileri sürülmektedir. Ev, gey kimliğinin icra edildiği bir yuva olarak tescil edilebildiği ölçüde, performatif bir alan olarak anlam kazanmaktadır. Bu performatiflik bireysel/kolektif, özel/kamusal, açı/gizli ikiliklerinin ötesinde yaratıcı ve olumsal bir kimlik icrasına perde aralar. Böylece, gey erkeklerin ev mekânı dolayımıyla tecrübe ettikleri habitusları insanlarla, nesnelerle ve yerlerle kurdukları muhtelif ilişkiler içerisinde gey kimliklerini tasdik etmelerine alan açar. Ancak bu tamamlanmamış bir projedir ve eşcinsel erkekler gündelik yaşamlarında bu ev yaşamını sürekli yeniden müzakere etmektedirler.

Anahtar Sözcükler: Cinselliğin Coğrafyaları, Eşcinsel, Yuva, Duygulanımsal Pratik, Habitus 


\section{INTRODUCTION}

Over recent decades, there has been tremendous interest in exploring sexualities in diverse spatial contexts. The primary focus has been on the constitution of sexualized spaces, and how they produce specific norms and regulate sexual practices (Brown, vd., 2007). In this ever-expanding body of literature, nonheterosexual practices and identities attract special attention; many studies scrutinize the construction and performance of non- heterosexual identities in different everyday places (such as night-time leisure venues, streets, workplaces and so forth). Some studies shed light on the production of normative standards that favour particularly gendered, classed, raced and sexualized bodies and practices, while marginalizing others (Binnie \& Skeggs, 2004; Held, 2015; Misgav \& Johnston, 2014; Taylor \& Falconer, 2015). Others examine diverse practices that make or unmake everyday places and foster non-normative discourses (Brown, 2008; Cattan \& Vanolo, 2014; Collins, 2005; Podmore, 2001).

In this context, the geographies of home are discerned as having particular significance in the individual and collective lives of lesbians and gays. Brown et al. (2007, p. 3) suggest that home - particularly the family home - becomes a site where relations and practices are governed by heteronormative discourses. Valentine et al. (2003) have shown that the younger generation's financial and emotional dependence on family hinders the capacity for constructing autonomous lesbian and gay identities. On the other hand, there are also many studies addressing the geographies of home as a site for fashioning lesbian/gay lifestyles (Elwood, 2000; Gorman-Murray, 2006a, 2006b, 2007, 2008; Johnston \& Valentine, 1995; Kentlyn, 2008). Gorman-Murray (2006b, 2007) suggests that the individual homes of lesbians and gay men are amenable to affirming non-heterosexual identities and subverting the cultural norms of heterosexual family life. Furthermore, Johnston and Valentine (1995) and Elwood (2000) contend that homes can be indispensable sites for community formation in locations where urban places for lesbian communities are limited.

This study contributes to understanding lesbian/gay identity construction of this type that takes place at home. Drawing on gay men's everyday experiences within Turkey's cultural context, I suggest that the 
home is laden with diverse meanings and affective registers (see Blunt \& Dowling, 2006; Blunt \& Varley, 2004). I demonstrate that, given the increasingly heteronormative cultural politics diminishing the performance of non- heterosexual identities in Turkey, homes have come to be the central site for sustaining difference. Home-making is, in this sense, an affective practice, effectively embedding safety and comfort within gay men's lives. I am using the term 'affective practice', borrowing from Wetherell (2012), to mean a flow of activities involving certain background feelings. As Wetherell states, this is a situated and relational process that gives rise to certain emotional dispositions in specific socio-cultural contexts.

From this vantage point, I argue that gay men's home-making as an affective practice facilitates safe and comfortable performance of gay identity. I illustrate that gay men's habitus within a strictly heteronormative cultural context informs a social knowledge of possible actions guiding gay men to reformulate and negotiate safety and comfort through home- making. This terrain of social knowledge effectively addresses the centrality of home to conducting a safe and autonomous course of gay life. Once safety and autonomy are achieved, gay men's domestic life becomes a space of comfort for performing gay identities. I am taking these affective dispositions (particularly comfort) as spatial affects which cultivate a degree of fit between one's performances and the physical setting (Holliday, 1999). Through this lens, insofar as gay men can reinscribe their homes as sites for the comfort of gay identities, those homes seamlessly become performative domains in which their situated activities pave the way for self-creation and self-affirmation. Therefore, I suggest that gay men's affective dispositions (namely safety and comfort) arise out of their relations with people, objects and places, and restructure their habitus in the way that they validate their gay identities in domestic life.

\section{AFFECTIVE PRACTICE AND HABITUS}

Recent debates dwell on affective dispositions as processual formations that involve embodied activities performed in relational, dialogical and situated contexts (Ahmed, 2004; Burkitt, 2014; Wetherell, 2012). In this strand of thought, emotion and affect derive from the lived experiences of individuals. They are also 
imbued with viscerally felt bodily sensations. Yet this theory is not predicated upon a physiological, biological understanding of emotion and affect. Burkitt (2014, p. 55) contends that social relations in diverse contexts give meaning to the embodied character of emotions; bodily sensations cannot be dissociated from how people see, imagine, experience and act in the social world. In that sense, affective practices, in Wetherell's (2012) account, bear the marks of feeling bodies and their constant movements in social life. They are elusive, slippery and, to some extent, ephemeral. However, Wetherell (2012, p. 13) states that affective practices can also be widely patterned and solidified. They may come to be characterized by shared dispositions across particular social categories or historical contexts. In order to understand the solidified and patterned aspects of affective dispositions, Addison (2017) suggests mobilizing Bourdieu's concept of habitus, as it facilitates an understanding of subject formation through terms of relationality, situatedness and practical process, in which emotional experiences and affective dispositions take their part.

Bourdieu identifies habitus as "systems of durable, transposable dispositions, structured structures, predisposed to function as structuring structures" (Bourdieu, 1990, p. 53). These dispositions display diverse patterns of thinking and feeling, and form individual and collective possible actions. They inform the knowledge of social practice which seems available to people. Insofar as habitus portrays an image of the social world through individual or collective trajectories, it comes to generate this system of dispositions, sensibilities and meaning making (Reay, 2004). This image carries the weight of emotional experiences and affective registers that guide subject formation. Habitus is thereby predicated upon a dynamic social space in which self and subjectivities come to be formed. In that sense, Addison (2017, p. 14) convincingly argues, this way of thinking provides an influential analytical lens that goes beyond a preexisting self.

By the same token, this way of thinking also paves the way for considering impromptu performances in the circumstances of one's incompatibility with social norms and expectations. These performances may 
indicate the unintelligibility of or unease about a situation in one's habitus, most times accompanied by a feeling of incongruity. They simultaneously bring about potentials for change and agency (Addison, 2017, p. 14). To a certain extent, individuals acquire a capacity to remake their ways of being and doing in the social world. They thereby actively struggle to validate themselves and invigorate their "feel for the game" (Bourdieu, 1990).

Regarding gay men's orientation towards home-making, social positions also play a formative role. Habitus takes quite different forms depending on people's social location and differential access to capital resources (Bourdieu, 1984). On that account, emotions research within a Bourdieusian framework is deemed to provide a static image in which certain affective styles are a virtual reproduction of structural relations (e.g. Burkitt, 2014). Here, I avoid drawing on an understanding of habitus as generating affective dispositions on the basis of fixed social positions. I instead utilize the notion of habitus in which creative and aesthetic practices and social constraints are intricately combined; in that regard, habitus is a site for creativity and improvisation on the one hand, and restriction and routine on the other (Wetherell, 2012, p. 105). I follow McNay's reading of Bourdieu's model of social practice: "Bourdieu's model restores a specific subject to action whose capacity to act arises from the interplay between emotional dispositions (habitus), social context (field) and class relations (structure and capital)" (McNay, 2008, p. 184-185). Here, agency is not reduced to one's position in the social structure, but rather, there is an active relation between one's habitus and one's social position. Viewed through this lens, I suggest that home-making, as an active relation between gay men's habitus and social structure, incorporates a social space for creativity and autonomy in their everyday life. 


\section{METHODOLOGY}

This study is based on 29 in-depth interviews conducted with gay-identified men in Ankara. The empirical material mainly comes from a larger research project seeking to understand class-based differences in gay men's construction and performance of their masculinities in Turkey, which was conducted in 2009-2010. After examining this data set, I realized that gay men's homes and domestic life are of great significance in the performance of their gay identities. For a more comprehensive understanding, I conducted 5 further interviews with gay men in 2017. This additional data conforms to the previous fieldwork in terms of sampling; the main characteristics of research participants in terms of age, occupation, household characteristics and so forth are more or less similar to before. The additional interviews were intended to obtain richer information about gay men's domestic experiences, what meanings they attribute to their homes and how their identity-construction processes are related to home-making.

The research participants were recruited through a snowball technique. I asked them to decide where the interviews would take place: 17 preferred to meet at their own or their friends' homes, with the other interviews conducted in such diverse places as cafés, university campuses and workplaces. All the interviews were recorded by means of voice recorder and lasted approximately 1-1.5 hours.

I have used the criteria for recruiting the participants in pursuit of representing diverse experiences of gay men in terms of the types of households, educational backgrounds, occupation and age differences. Twentytwo of the participants had autonomous lives, living alone, or with their partners or housemates. The remaining 7 were living with their families; 2 were married with children, and the others were living with their parents. The participants' ages ranged from 22 to 48. Eleven of the participants had high school or lower degrees and were socio-economically disadvantaged, employed in low-skilled and low-waged jobs such as salesperson, hairdresser, or delivery driver, or unemployed (one out of twenty-nine) at the time of the fieldwork. Others (eighteen in total) had university degrees and were employed in well-paid professional 
jobs in industries such as engineering, finance, health, and education, or were students studying at prestigious universities.

In the interviews, I have investigated how gay men think and feel about being gay in their ordinary life; how they see themselves and others, their practices, beliefs, values, and so on; the ways that they perform their gay identities in specific social and spatial contexts (with marked attention to home life); and finally, which affective registers they attribute to their everyday experiences. I dealt with gay men's narratives as speech acts charged with their thoughts and feelings concerning their lived experiences. The methodological approach drawn upon in this study sees these narratives as elaborately rooted in the men's social positions in specific socio-cultural contexts (Chase, 2005). In that regard, I have considered the narratives to be situated practices through which gay men give meaning to their social world.

Dealing with these narratives has also engendered an influential strategy for exploring the men's affective dispositions: how people narrate stories about their presence in the world potentially communicates their emotions (Gabriel \& Ulus, 2015). Therefore, I have paid particular attention to the interviewees' affective styles and intensities in their narratives. That said, these affective styles are not necessarily found in firstperson emotional expressions. Wetherell $(2012$, p. 72) states that people's speech acts are definitely felt, although they may not be verbally expressed. Thus, the primary concern is to investigate how people's speech acts are overwhelmed by certain affective dispositions.

\section{CULTURAL POLITICS OF QUEER SEXUALITIES IN TURKEY}

The ordinary lives of LGBTQ communities have been trenchantly marked by heightened levels of marginalization in Turkey. Lacking legal protection and cultural recognition, LGBTQ individuals are liable to severe levels of discrimination. Y1lmaz and Göçmen (2016) demonstrate that discriminatory discourses and practices are especially prevalent in the fields of employment, housing and healthcare. Likewise, a nationally representative survey published in 2007 shows that lesbians and gays are the most shunned 
groups in Turkish society (Çarkoğlu \& Toprak, 2007). Indeed, according to Ozyegin's (2012, p. 207) study, the more pious individuals are, the more they show negative attitudes towards lesbians and gays.

Such a compelling cultural climate is delicately manifested in the political domain. The AKP government, which has had massive electoral power since 2002, has been the ruling authority enthusiastically carrying this climate a step further. The party earnestly sets forth a political project seeking to impose a conservative image of society and reinforce pious, family-based conduct of social life. In particular, political discourses marginalizing queer sexualities (coupled with pro-natalist discourses, anti-abortion campaigns, and so forth) have conspicuously come to the fore (Acar \& Altunok, 2013; Beşpınar, 2014; Cindoglu \& Unal, 2017; Korkut \& Eslen-Ziya, 2016; Sümer \& Eslen-Ziya, 2017).

The proliferation of conservative discourses has had a heavy influence on queer activism and culture, and the voices of LGBTQ identities are overwhelmingly unheard, disregarded and silenced (Ataman, 2011; Güney \& Selçuk, 2016). A stunning example is the ban on Istanbul's pride parade since 2016. Shortly before the marches, Islamist and nationalist groups reprimanded demonstrators for not conforming to local cultural values, an idea they based on the fact that the gay pride events coincided with the holy month of Ramadan. Shortly after, Istanbul's governor's office banned the events on account of security concerns.

This precarious situation compels the LGBTQ population to construct and perform their identities on a negotiated basis (Bereket \& Adam, 2008; Erol \& Ozbay, 2017; Ozyegin, 2012). Eslen-Ziya and Koç's study (2016) focusing on gay men in Turkey, for instance, argues that the fear of being stigmatized causes them to conform to the cultural ideals of gender normativity. Yet these ideals portray plural gender identities; Ural and Beşpınar (2017) assert that there are contesting definitions of masculine respectability, which are differentiated in terms of class. In this plurality, there exists a relative autonomy of gay performances in spaces of middle-class lifestyles, resulting in greater capacity to escape from marginalizing discourses. However, in the body of literature concerning the negotiations for constructing gay selves in Turkey, spatial 
strategies are mainly disregarded. Wimark's (2016) study is the exception, illustrating mobilities of lesbians and gay men due to education and employment trajectories. Wimark reveals that these trajectories are essentially empowering in terms of maintaining socio-spatially autonomous lesbian and gay selves. As I illustrate below, gay men's home-making practices are also amenable to discerning the spatial dimensions of negotiations to perform gay identities in Turkey.

\section{GAY MEN'S HOME-MAKING PRACTICES IN ANKARA}

Home is widely discerned as a site that lies at the very centre of the heterosexual nuclear family. Accordingly, home-making is deemed to be characterized by heteronormative discourses and practices, diminishing the construction and performance of queer identities (Duncan, 1996, p. 137). For instance, Johnston and Valentine's (1995) study indicates that lesbian women govern their embodiment and spatial practices through "covering their tattoos", "dressing conservatively" and having "a straight-looking appearance" in their family homes. Yet, home (mostly individual homes) can also be amenable to placemaking by means of which individuals can enjoy their individuality. Despite home's association with heterosexuality and the ideals of family life, not all home dwellers are heterosexually-identified individuals and the home per se does not necessarily constitute a domain for heterosexual performativity. From this vantage point, there does exist potential for the home to be re-inscribed with queer practices.

The re-inscription of the home as a gay place is especially evident in gay men's lived experiences in Ankara. In the urban context of Ankara, where this research has been conducted, the public presence of queer cultures is limited. Although the most prominent human rights organizations advocating LGBT rights are based in Ankara, the city does not offer much for queer cultures. At the time of the fieldwork, there was only one nightlife venue catering to gay men. Such a scarcity of leisure places translates into gay men feeling out of place in Ankara's urban life. Consequently, their homes are central to their spatial strategies. 
The home thereby becomes a polyvalent space, which is potentially deconstructed and reconstructed through lived experiences. Iris Marion Young (2005) asserts that home-making is invested with creativity and individuality so that home "support[s] [a person's] life activities and reflect[s] in matter the events and values of his or her life" (Young, 2005, p. 139). In such a concept, the home is not merely a store of personal belongings and memories, but a spatial domain that is actively engaged with the formation of subjectivities. Ongoing and sustained processes of domestic life realise in the home a dynamic site in which self is fabricated in a way that reflectively manifests needs and tastes. Habitual actions and routines generate a home that is a multi-layered space and give diverse meanings to that space's materiality. Invested with creativity and individuality, lived experiences transform the physical space of the home into a performative site and connect the home to identity formation (Young, 2005, p. 153).

\section{Safety and Autonomy at Home}

To the extent that gay men feel deeply out of place in a heteronormative cultural context, they show a disposition toward acquiring safety and autonomy through home-making practices. Their narratives reflect an image of a social world, which is profoundly conservative, heteronormative and in sharp contrast to gay sexuality. It follows that gay men seek to cultivate their everyday life through home-making practices, rendering a retreat from heteronormativity possible. Home-making becomes central to their sense of selves that legitimates their "feel for the game" (Bourdieu, 1990) as a gay man. For instance, Emirhan, who is a 34-year-old professional employed in the construction industry and living alone, recounts that a focus on home life is inevitable, due to the public's hostility to gay sexuality:

There are some rules of society. You can do certain things inside your home. You cannot be a gay in the street, say. Of course, there are some people who do it in this way, but this is quite dangerous. You have to adapt yourself to the standards of conservatism.

Emirhan takes the social norms for granted and he feels obliged to conform to these ideals. He strictly discerns that being identified as a gay man violates the social rules and brings about the threat of gay 
bashing. He therefore avoids publicly presenting as a gay man. Such personal accounts rely upon the idea that one should avoid public displays of gay identification, and lead to spatial practices that locate gay performativity within one's domestic life. In that regard, beneath gay men's pursuit of safety in domestic life lies the desire to escape threats of homophobic violence and discrimination.

Indeed, gay men's narratives reveal that one's own home may also support a heightened perception of autonomy and empowerment. Onur, a 35-year-old teacher working in a public high school and living alone, explained how he felt sufficiently determined and courageous to come out to his mother shortly after obtaining independence in economic and emotional terms:

I have a job and a home, so I easily came out to my mother as I am not dependent on her. I told her that if you don't accept me, then I won't see you again. That was so simple. And she accepted me because she had to. Now it is going well with her.

Likewise, Metin - a 34 year old professional working in finance sector and living alone -says that he felt strong enough to come out after setting up his own independent life in his home.

I decided to come out to my mother after having an independent life. After graduation, I found a job and moved to my own home. Then I had that courage to come out to my mother. Now she seems OK with that, although we don't talk about that much.

Ozyegin (2012, p. 213) suggests that familial ties are robust cultural imperatives that play a crucial role in the construction and presentation of public selves. Connectivities with the family that are deeply informed by indebtedness and loyalty cater for relational, rather than autonomous, selves. Therefore, tensions come to the fore between one's relationality with the family and autonomy for a gay life (Ozyegin, 2012, p. 216; Wimark, 2016, p. 664). Gay men's stories of setting up independent lives, as quoted above, suggest how influential it is to feel self-empowered. Leading their lives in their own homes, gay men's self-image is 
informed by individual empowerment, in terms of both financial and emotional wellbeing. They could then confidently demand recognition and respect from their families.

Gay men's self-empowering strategies based on setting up one's own life firmly depend, however, on their capacities to lead such an autonomous life; not all gay men can attain it, as opportunities to do so are complexly structured by their differential access to capital resources. Above all, these dynamics concern educational trajectories during gay men's lives that legitimate or hinder 'leaving the nest'. For some gay men, leaving the family home with the intent of studying in Ankara, where a number of highly prestigious and top ranked public and private universities are located, simultaneously opened up a space to cultivate novel subjectivities outside the gaze of family members. In this context, they narrate the extension of their capacities to construct and perform gay subjectivities during the time that they studied away from their family homes (see also Wimark, 2016, p. 664). Yet for those staying in their family homes whilst studying in Ankara, young adulthood is a stage of life during which they fail to escape from the watchful eyes of family. Besides, Ural and Beşpınar's (2017, p. 252) study on the dynamics of class in the gay performativity suggests, to the extent that gay men suffer from material deficiencies, familial ties provide them with social capital; they get the benefit of material support and care, including perhaps living with their parents ${ }^{2}$.

Being strongly tied to their families, these gay men cultivate a relational self that portrays a different image of domestic life. The way that they draw material and emotional advantage from familial support translates into the family's watchful eyes weakening the capacity to fashion a gay life. In that regard, the idea of home as a site for safe and autonomous gay life persists, although more as a dream that they hope to consummate

2 According to Ural and Beşpınar's (2017) study, gay men's class positionings strongly inform their sense of selves and performance of their identities. Accordingly, disadvantaged class positions translate into cultural and/or material dependence to their families. This relationality gives rise to maintenance of heteromasculine ideals of familialism and leaves little room for fashioning an autonomous gay life. Besides, gay men of privileged class positions acquire a distinct capacity for individual autonomy that makes room for construction and performance of gay identities. In that regard, gay men's capacity for fashioning a gay life is severely structured by class differences.

$\mathrm{SAD} / \mathrm{JSR}$

Cilt / Volume 24 Say1 / Number 2 
in their future lives. Despite their financial or emotional dependence to their families, they maintain the ideal of home-making in pursuit of fashioning a gay life. For example, İlkay, a 37-year-old unemployed man living with his parents, illustrates the centrality of living on his own as a criterion for leading an autonomous life, as follows: "If I could have a job and live on my own, my life would be entirely different. I wouldn't have to tell where I am, with whom I am going out.” Likewise, Görkem, a 22-year- old university student living with his parents, sees living independently in his own place as a life goal that, if achieved, will radically transform his capacities to conduct an autonomous gay life:

...now, I am dependent on my family. I have to tell them where I am when outside. I feel a constant surveillance on me... But one day, I will be far away from them, earning my life and living in my own place.

Gay men vigorously attribute the meanings of safety and/or autonomy to living independently in their own homes. Individual homes are discerned as socio-spatial settings in which possible actions toward fashioning a gay life take place. Home-making comes to the fore as a socio-spatial practice that potentially reflects the habitus of gay life. On the one hand, it is deemed a 'safe haven' to escape from homophobic violence and discrimination; on the other, it takes on the meaning of autonomy and independence from the family, either imagined or experienced. These meanings derive from the potentials of home as a social space that is relatively emancipated from the judgment of others, namely discriminatory practices of public life, and familial control and discipline.

\section{Home as the Space of Comfort}

In as much as gay men are fortified by autonomously safe individual spaces, they re-appropriate the home as a venue catering for construction of gay identities. This is an unfinished project, being realized through flows of activities in everyday life. It is thus a practical process, shaped by habitual actions taking place at home. The ways that gay men re- inscribe their homes through these activities effectively reflect a specific form of habitus accommodating spaces of comfort for performing gay subjectivities. 
Holliday (1999, p. 481) conceives of comfort as a particular form of affect, informed by the degree of fit between one's own body and its exterior. Thus, comfort is specifically a spatial feeling that is laden with gendered and sexualized meanings (Held, 2015). The extent to which particular performances are imagined as being compatible with culturally exalted forms in certain spatial contexts gives rise to the feeling of comfort. Conversely, incompatibility leads to the feeling of discomfort, exerting a discursive pressure to perform particular bodily practices conforming to gender and sexual normativity (Held, 2015, p. 37). Thus, comfort derives from imaginings of being respectable and recognizable while performing in specific ways.

The discursive meaning-making of comfort described here falls in with diverse accounts assessing lived experiences. As Wetherell (2012, p. 72-74) contends, this is a relational moment at which one's social experiences give rise to specific emotions and shape subjectivities. In that sense, affective practices (such as comfort) are much at work (although not directly communicated through first-person speech acts like 'I feel comfortable'). Affective practices are thus entangled in situated activities and the ways that they are discursively represented (Wetherell, 2013, p. 360).

Gay men interviewed in this study narrate their domestic life within this discursive terrain of comfort. They reveal that they cultivate a degree of fit between their bodily performances and their domestic life by means of intricate relations with their belongings that effectively demonstrate their affective disposition of comfort with gay identity at home. One part of this process concerns gay men's intimacy and sexual practices. They furnish their home with objects that are particularly associated with gay sexual cultures. The use of these objects facilitates or increases sexual pleasure and excitement. They thereby manifest gay erotic habitus that are directly invested with sexual meanings (Green, 2008). Moreover, home comes to the fore as a space of erotic habitus in which these objects are stored and experienced. For instance, Necip, a 33-year-old public servant living with his partner, points out a number of sex toys, jockstraps, and similar items and substances, which he mainly purchased from online stores or erotic shops abroad. In his view, although they are not necessarily related to homoerotic intimate life, these objects are symbolic and material markers of gay 
identity. In saying this, he displays an intensity of domestic comfort, as home is an indispensable place where he can escape from the judgment of others and enjoy intimacy:

This is the place that I can have and use certain things. I have got cock rings and lubricants at home. They are apparently really gay, I believe. Even a bundle of jockstraps. My partner and I like them so much. Very few straight people use them. That way, I think that they are markers of our identity. Some gay men utilise posters, movies, books and so forth that are symbolically marked by gay culture. In their view, their homes are ornamented with these cultural products and decorative items to construct and sustain gay identity. For instance, Toprak speaks of a gay-themed movie poster hanging in his living room, as well as various gay-themed novels and non-fiction books focusing on gender and sexualities. As a 32year-old academic interested in the field of gender and sexualities, he sees these items as a reflection of his gay identity: "I have this poster of a movie telling a story of gay love. I have many books about gay issues and sexualities. I think all make it feel like the house of a gay man, as I am.”

These examples demonstrate how gay men extend their identities into their home through the medium of materiality. Such materiality demonstrates their affective dispositions of comfort that open up a space for gay performativity. They draw attention to specific belongings that are not merely the markers of their gay identities but also a medium of 'feeling at home' as a gay man in his domestic life. The feeling of comfort here operates as a "naturalizing discourse" (Holliday, 1999, p. 481) that restructures gay men's habitus, that is, their knowledge of possible actions available to them. In this sense, this affective register paves the way for the formation of gay subjectivity on a relational, situated and practical basis, echoing Bourdieusian analytical framework. That is to say, the comfort of home paves the way for re-naturalization of gay embodiment in gay men's domestic life. Gay men acquire a distinctive capacity for gay performances as the feeling of comfort translates into a spatial experience that validates gay life.

$\mathrm{SAD} / \mathrm{JSR}$

Cilt / Volume 24 Sayı / Number 2 
Yet this 'comfort of home' is not simply an individual experience of gay identity; it is also manifested in gay men's interactions with others, usually other gay men. It is in this way that gay men negotiate the boundaries between public/private distinctions. Duncan (1996, p. 129) suggests that these distinctions are not predicated upon homogeneous spatial categories; public and private spaces are closely linked and interwoven. Diverse practices of gay men interacting with other gay men parallel this understanding of public/private distinctions. To the extent that they open up their homes as venues to have encounters and establish companionship and/or intimacy with others, they introduce a degree of publicness into their homes (Gorman-Murray, 2006b, p. 65). This transforms individual homes into cultural spaces of gay lifestyles, where the comfort of gay identity is collectively experienced.

Mehmet, a 37-year-old salesperson who is a minimum wage earner and living with his mother, illustrates how he comes to experience his friends' homes as cultural venues. His accounts reveal the home as a location for partying enjoyed by circles of friends, making room for a cultural formation of gay lifestyles outside the heteronormative public gaze. In such a way, possibilities arise to transgress the social norms, for example, by violating the cultural ideals of gender performances in diverse 'funny' ways. In his view, these 'funny' moments avoid the heteronormative gaze and are by no means a disruption of comfort:

We come together in a friend's home, owned by one of us, on a regular basis. We really enjoy those times because there is no one around who would find us strange. I don't care whether I am too feminine or anything. We have alcohol and enjoy quite different things that we find funny to do. We may act in a feminine way or wear a skirt. And we find these kinds of things quite funny. I can't deny that.

Once gay men remake their homes as places of comfort for gay identity, diverse practices and relations become amenable to resignification in a queer way. Following Bourdieu's (1990) model of social practice, this process is an interplay of creative agency and situatedness. Gay men actively engage with the social 
context and redefine the contours of possible actions. In that regard, gay men remake their subjectivities in their activities of home-making. A stunning example concerns specific marriage rituals that are particularly associated with heterosexuality. Necip (33, public servant, living with his partner) and his partner organized a henna night to celebrate their relationship. Inviting a few close friends, they re-appropriated this wedding custom as a gay rite of passage. Henna nights traditionally belong to Muslim- majority cultures. Although it has usually been a female ritual, its contemporary variants can be gender-mixed events, mostly held in the bride's family home. The ritual typically involves praying, dancing and the colouring of palms using henna. Necip and his partner re- interpreted this tradition and transformed it into a local cultural element of gay life. In a sense, their practice was an appeal to local cultural values; they maintained almost all of the conventional elements, but remade this cultural tradition as a ceremonial expression of their relationship. In this way, they extended the elements of heterosexual cultures into gay lifestyles.

Otherwise, gay men's collective enjoyment of domestic life is largely accomplished by means of digital cruising apps, including those using location-based mobile technologies. As a matter of fact, this sort of cruising constitutes a digital spatial setting that can be employed in diverse physical places. Yet gay men I interviewed stated that they mainly use it while at home. In this way, gay men extend their individual comfort of gay identity into a semi-public sphere, in which they take the opportunity to make and maintain connections with other gay men. As Ahlm (2017) suggests, digital cruising practices are ambivalently linked to public/private distinctions. On the one hand, these practices are socio-spatially dissociated from the predominantly heteronormative public space. In a socio-cultural environment that is hostile towards queer sexualities, these media could be used as a strategy to govern visibility and maximize safety (Davis vd., 2016). On the other hand, the users get the opportunity to form a mode of public gay identity through public profiles and online messaging. Gay men extend the boundaries of their home place and make connections with the outside world. As this form of extension is effectively selective, it escapes the heteronormative public gaze while simultaneously being accessible to the gay gaze. 
Given that gay men can hardly be a part of urban cultures in a city like Ankara, the role of digital cruising becomes strongly accentuated. Kerem, for instance, a 28-year-old professional in the health sector who lives alone, thinks that Ankara promises almost nothing in terms of encounters with others. Yet, for him, the Internet steps in and opens the door into a gay life without disrupting the comfort of home:

The Internet means a lot to me. I can have sex, make friends, and even fall in love. All that I can hardly find anywhere else here in Ankara. But on the Internet, while home, it's that easy to talk and meet up with other gays... We badly need these closed places. They help us make alternatives.

Johnston and Valentine (1995) point out that lesbians' homes function as meeting places in a way that fills the entertainment gap in locations where institutional places for lesbian women are substantially lacking. Lesbian women's homes thereby emerge as semi- public spaces, advancing subcultural formations of queer lifestyles. The accounts of the gay men quoted above mirror these spatial strategies. Given that gay men are truly deprived of an urban presence, as gay urban cultures are quite limited and highly marginalized, private homes are inevitably central to gay cultural formations. Inasmuch as gay men's use of the home for partying or cruising sets the stage for diverse activities, their domestic life paves the way for both individual and collective comfort of gay identity. Homes therefore accommodate the collective and comfortable enjoyment of gay life.

\section{Negotiating Safety and Comfort through Spatial Practices}

The formation of home-based gay subjectivities is highly vulnerable and liable to be undermined by a certain mode of public gaze that delves into private life. Gay men regularly feel the watchful eyes of their neighbours, whether imagined or experienced, and this gives rise to concerns over the visibility of their gay identification. Correspondingly, they seek to negotiate the boundaries between their private life - in which they constitute gay sociality through the terms of safety and comfort - and their public life, effectively silencing and marginalizing queer cultures. 
To bridge this distinction, they employ several strategies. They make efforts both to maintain their style of gay life and to escape the notice of the heteronormative public. That is to say, their spatial strategies basically seek to govern their appearance in the eyes of others, while simultaneously sustaining the emotions of safety and comfort. One way of doing this involves the materiality of their houses; gay men are liable to have homes with specific characteristics that ensure heightened privacy. To illustrate, Necip (33, professional, living with his partner) states that sensitivity compels them to live in a place located on the upper floors; living in a top floor flat in central Ankara, he and his partner enjoy their intimate life out of the view of others. Likewise, Mehmet, a 35-year-old engineer living alone, says that he is overwhelmingly concerned about thoroughly drawing the curtains, especially at times when he has intimate moments with his partner.

More importantly, these concerns are also reflected in gay men's relations with other gay men. As illustrated above, gay men remake their homes as venues that pave the way for gay sociality. Yet, to the extent that their homes become semi-public spaces, this increasingly gives rise to concerns about being exposed as a gay man in their neighbourhoods. To that end, they set specific rules that regulate who enters their homes. Establishing sharp demarcations, they avoid the presence of certain bodies and practices in their domestic environments, believing that others would find them strange and inappropriate. Gay men's appeal to gender conformity is the most typical illustration of this point. In their accounts, those who are not conforming to the culturally exalted forms of gender performances are rigorously unwelcome. This can be clearly seen in the narratives of Eray, a 39-year-old professional in the IT sector, who is living alone:

Almost all of the neighbours in the apartment block know me and my family very well. They are also a kind of snoopy type. If I have a guest, they always want to know about this person. If I bring a gay man, whom I met through the Internet, I introduce him as a relative of mine or someone from my workplace. But, for this reason, I would never invite someone feminine. I don't want them to get suspicious. 
This is also true in the case of Mehmet (35, engineer, living alone); he certainly denies the presence of gender practices that are incongruous with cultural norms in his home:

I wouldn't like to give an impression that gays came together in my place. That is why body characteristics are very important. I don't let a very effeminate gay come into my place. I can't let my guests draw people's attraction. He shouldn't be too flamboyant. I think this is about clothes, attitude or something. Some even put on makeup, paint their nails or wear women's clothes.

In pursuit of complying with societal expectations, gay men immediately fit into the normative definitions of masculinity. Eslen-Ziya and Koç's (2016, p. 804-805) study shows that the appropriation of these norms leads to gay men's prejudice towards effeminacy in gay embodiment. They suggest that gay men replicate the existing stigmatization in their pursuit of social acceptance in a highly heteronormative cultural context. The accounts of gay men quoted above resonate with this idea, revealing that gay men's interest in social acceptance results in socio-spatial demarcations excluding unequivocally gay performances. 


\section{CONCLUSION}

This study has examined the construction and performance of gay subjectivities through home-making as affective practice in Turkey. In doing so, it has followed Wetherell's (2012) conception of 'affective practice' as flows of activities involving some background feelings that can be solidified and patterned across the lines of spatial contexts, social relations and cultural particularities. Drawing on in-depth interviews conducted with gay-identified men, I see the centrality of home-making as an affective practice that advances the making of gay selves through the terms of safety and comfort. Gay men's flows of activities taking place at home produce a performative domain; they mobilize the men's creative capacities to construct their gay identities by means of investing in their subjectivities through self-affirming affective styles. Yet this is an unfinished project. Gay men constantly avoid bold visibility in public life due to the fear of being judged, discriminated against, gay bashed, and so on. Instead, they seek to maintain their fashion of gay life at home through diverse spatial strategies. They carefully govern their home-based activities in pursuit of a retreat from the strictly heteronormative public gaze in Turkey.

This study suggests that gay men's affective practices come to be informed by their habitus. Bourdieu (1990, p. 55) conceives habitus as a social space that accommodates an "infinite capacity for generating products - thoughts, perceptions, expressions and actions"; yet this capacity is predicated upon neither "creation of unpredictable novelty" nor "mechanical reproduction of the original conditioning".

Viewed through this lens, gay men's pursuit of safety and comfort within a heteronormative cultural context generates knowledge of possible actions that are channelled into home-making practices. An equivocal character therefore characterizes gay men's domestic life. Inasmuch as their tendency to domesticity is rooted in the cultural politics of heteronormativity, gay men simultaneously re-inscribe spaces of home with their affective dispositions. However, gay men's inclination to perform their identities through home-based activities is complexly structured by their social positionings. Gay men's dependence to their families (as exemplified by those suffering from material deficiencies or university students devoid of individual 
financial resources) may have much less capacity to leave the family home and establish an independent and autonomous home life. On that account, the home-based habitus of gay life is intricately linked with gay men's differential access to capitals.

Finally, it should be noted that the spatial practices of gay men illustrated here are not simply reminiscent of the 'gay closet', in a sense that gay life is repressed and gay identities are laden with the feelings of guilt, shame and solitude. Similar to what Seidman, Meeks and Traschen (1999, p. 15) suggest, a protective space is created in which public exposure is minimized or defused. As the socio-political and socio-cultural context of Turkey informs a public life which undermines the performance of gay lifestyles, gay men carve out their spatial practices in ways that enable them to lead a safe and comfortable life. Thus, the homebased fashion of gay life facilitates governing one's display of gay identification. Practices of attenuating gay life outside the home involve nothing short of negotiating to whom and to what extent gay selves would be presented. 


\section{ÖZET}

Son yıllarda cinselliklerin farklı mekansal bağlamlarda nasıl tecrübe edildiğine büyük bir ilgi gösterilmektedir. Güncel çalışmalar cinselleşmiş mekanların oluşumu ve bu mekanların nasıl özgün normlar ürettiği ve cinsel pratikleri düzenlendiğine dikkat kesilir (Brown vd., 2007). Bu literatür heteroseksüel olmayan pratiklere ve kimliklere özel bir ilgi duyar; çalışmalar genel olarak (eğlence mekanları, sokak, işyeri gibi) farklı gündelik mekanlarda heteroseksüel olmayan kimliklerin inşa ve icra edilmesini inceler. Bazı çalışmalar cinsiyetli, sınıflı, 1rksallaşmış ve cinselleşmiş beden ve pratikleri tasdik eden normatif standartları konu eder (Binnie \& Skeggs, 2004; Held, 2015; Misgav \& Johnston, 2014; Taylor \& Falconer, 2015). Bazı çalışmalar da normatif standartların dışına çıkan söylem ve pratiklerin üretildiği gündelik mekansallıkları mercek altına alır (Brown, 2008; Cattan \& Vanolo, 2014; Collins, 2005; Podmore, 2001).

Bu bağlamda, ev mekanı lezbiyen/gey kimliklerinin inşa edilmesinde özel bir öneme sahiptir. Brown vd.'nin (2007, s. 3) belirttiği gibi, ev -özel olarak da aile evi- heteronormative söylemlerin üretildiği ilişki ve pratiklerin başat mekanıdır. Örneğin, Valentine vd. (2003) aileye maddi ve duygusal olarak bağımlı olan genç kuşakların özerk bir biçimde lezbiyen/kimliği inşa etmesinin güçlüklerini öne sürerler. Bunun yanı sıra, evselliğin (domesticity) lezbiyen/gey kimliklerinin ve yaşam tarzlarının icra edilmesinin mekanı olarak kavranabileceğine işaret eden çok sayıda çalışma da vardır (Elwood, 2000; Gorman-Murray, 2006b, 2006a, 2007, 2008; Johnston \& Valentine, 1995; Kentlyn, 2008). Örneğin, Gorman-Murray (2006b, 2007) ev yaşamının heteroseksüel olmayan kimlikleri içerme ve baskın kültürel normları istikrarsızlaştırma potansiyeline vurgu yapar. Johnston ve Valentin (1995) ve Elwood (2000) da, lezbiyen toplulukların tecrübelerine odaklandıkları çalışmalarda, kent yaşamının bu gruplara sınırlı olanaklar sunduğu mekansal bağlamlarda evin topluluk kültürünün oluşumunda oynayabildiği merkezi role değinirler.

$\mathrm{Bu}$ çalışma, lezbiyen/gey kimliklerinin inşa edilmesinin mekansal dinamiklerinde evsel yaşamın sunduğu imkan ve sınırlılıkları sorunsallaştırarak bu yazına katkı koymayı hedeflemektedir. Türkiye'de kendisini 
eşcinsel olarak tanımlayan erkeklerin gündelik deneyimlerine dayanan araştırmadan hareketle, evin muhtelif anlamlarla ve duygulanımlarla tanımlanabildiği ileri sürülmektedir (bkz. Blunt \& Dowling, 2006; Blunt \& Varley, 2004). Sarih bir biçimde heteronormatif bir kültürel iklimde heteroseksüel olmayan kimliklerin icra edilmesinin sınırlandırıldığı ölçüde, ev farkı kuran ve idame eden performatif bir alan olarak kurgulanmaktadır. Bu bağlamda, yuva kurma duygulanımsal bir pratik olarak eşcinsel erkeklerin güvenlik ve konfor arayışlarının sonucu olarak gelişir. Burada 'duygulanımsal pratik' terimi Wetherell'in (2012) eylem repertuvarlarının belirli bir arkaplan duygusuyla geliştiğine işaret eden kuramsal çalışmasından ödünç alınarak kullanılmaktadır. Wetherel'in belirttiği gibi, bu süreç konumlu (situated) ve ilişkisel bir süreçtir; özgün sosyo-kültürel bağlamlarda belirli duygusal yatkınlıklar yaratır.

Buradan hareketle, eşcinsel erkeklerin duygulanımsal pratiği olarak yuva kurma edimlerinin gey kimliğinin inşa ve icra edilmesinde önemli bir rol oynadığını öne sürüyorum. Eşcinsel erkeklerin heteronormatif bir kültürel iklimin yapılaştırdığı habitusları içerisinde, ev yaşamı eylem repertuvarlarının merkezinde konumlanıyor. Eşcinsel erkekler ev yaşamına yönelen bir toplumsal bilgiyi kullanarak kendi benliklerini, kimliklerini, pratiklerini ve ilişkilerini anlatılaştırıyorlar. Bu toplumsal bilgi güvenli ve özerk bir gey yaşamının mekanı olarak evi işaretliyor. Bu duygulanımsal yatkınlıkları, kişinin edimleri ve fiziksel ortamı ile bir uyumu gösteren mekansal hisler olarak kavrıyorum (Holliday, 1999). Bu açıdan, ev yaşamı gey kimliğinin konfor alanı olarak işaretlendiği ölçüde, yaratıcılığın ve benliğin tasdik edildiği performatif bir alan haline geliyor. Dolayısıyla, eşcinsel erkeklerin duygulanımsal yatkınlıkları insanlarla, nesnelerle ve yerlerle ev eksenli bir ilişkiselliği tesis eden gey habitusu üretiyor. 


\section{REFERENCES}

Acar, F., \& Altunok, G. (2013). The 'Politics of Intimate' at the Intersection of Neo-Liberalism and NeoConservatism in Contemporary Turkey. Women's Studies International Forum, 41, 14-23. https://doi.org/10.1016/j.wsif.2012.10.001.

Addison, M. (2017). Overcoming Arlie Hochschild's Concepts of the 'Real' and 'False' Self by Drawing on Pierre Bourdieu's Concept of Habitus. Emotion, Space and Society, 23, 9-15. https://doi.org/10.1016/j.emospa.2017.01.003.

Ahlm, J. (2017). Respectable Promiscuity: Digital Cruising in an Era of Queer Liberalism. Sexualities, 20(3), 364-379. https://doi.org/10.1177/1363460716665783.

Ahmed, S. (2004). The Cultural Politics of Emotion. Edinburgh University Press.

Ataman, H. (2011). Less than Citizens: The Lesbian, Gay, Bisexual and Transgender Question in Turkey. In R. Ö. Dönmez \& P. Enneli (Ed.), Societal Peace and Ideal Citizenship for Turkey (p. 125-158). Lexington.

Bereket, T., Adam, B. D. (2008). Navigating Islam and same-Sex Liaisons among Men in Turkey. Journal of Homosexuality, 55(2), 204-222. https://doi.org/10.1080/00918360802129428.

Beşpınar, F. U. (2014). Women and Gender. In B. Shane \& M. Herzog (Ed.), Turkey and the Politics of National Identity: Social, Economic and Cultural Transformation (p. 118-144). IB Tauris.

Binnie, J., \& Skeggs, B. (2004). Cosmopolitan Knowledge and the Production and Consumption of Sexualized Space: Manchester's Gay Village. The Sociological Review, 52(1), 39-61. https://doi.org/10.1111/j.1467-954X.2004.00441.x.

Blunt, A., \& Dowling, R. (2006). Home. Routledge.

Blunt, A., \& Varley, A. (2004). Introduction: Geographies of Home. Cultural Geographies, 11, 3-6. https://doi.org/10.1191/1474474004eu289xx.

Bourdieu, P. (1984). Distinction: A Social Critique of the Judgement of Taste. Harvard University Press.

Bourdieu, P. (1990). The Logic of Practice. Polity Press.

$\mathrm{SAD} / \mathrm{JSR}$

Cilt / Volume 24 Sayı / Number 2 
Brown, G. (2008). Ceramics, Clothing and Other Bodies: Affective Geographies of homoerotic Cruising

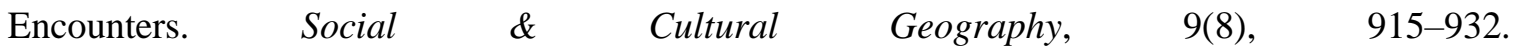
https://doi.org/10.1080/14649360802441457.

Brown, G., Browne, K., \& Lim, J. (2007). Introduction, or Why Have a Book on Geographies of Sexualities? In K. Browne, J. Lim, \& G. Brown (Ed.), Geographies of Sexualities: Theories, Practices, Politics (p. 1-20). Ashgate.

Burkitt, I. (2014). Emotions and Social Relations. Sage.

Çarkoğlu, A., \& Toprak, B. (2007). Religion, Society and Politics in a Changing Turkey. TESEV Publication.

Cattan, N., \& Vanolo, A. (2014). Gay and lesbian Emotional Geographies of Clubbing: Reflections from Paris and Turin. Gender, Place \& Culture, 21/9, p. 1158-1175. https://doi.org/10.1080/0966369X.2013.810603

Chase, S. (2005). Narrative Inquiry: Multiple Lenses, Approaches, Voices. In N. Denzin \& Y. S. Lincoln (Ed.), The Sage Handbook of Qualitative Research (p. 651-680). Sage.

Cindoglu, D., \& Unal, D. (2017). Gender and Sexuality in the Authoritarian Discursive Strategies of "New Turkey". European Journal of Women's Studies, 24(1), 39-54. https://doi.org/10.1177/1350506816679003.

Collins, D. (2005). Identity, Mobility, and Urban Place-Making: Exploring Gay Life in Manila. Gender \& Society, 19(2), 180-198. https://doi.org/10.1177/0891243204272707.

Davis, M., Flowers, P., Lorimer, K., Oakland, J., \& Frankis, J. (2016). Location, Safety and (Non) Strangers in Gay Mens Narratives on Hook-Up Apps. Sexualities, 19(7), 836-852. https://doi.org/10.1177/1363460716629334.

Duncan, N. (1996). Renegotiating Gender and Sexuality in Public and Private Spaces. In N. Duncan (Ed.), Bodyspace: Destabilizing Geographies of Gender and Sexuality (p. 127-144). Routledge. https://doi.org/10.1017/CBO9781107415324.004

Elwood, S. (2000). Lesbian Living Spaces: Multiple Meanings of Home. Journal of Lesbian Studies, 4(1), $11-27$. 
Erol, M., \& Ozbay, C. (2017). No Andropause for Gay Men? The Body, Aging and Sexuality in Turkey. Journal of Gender Studies, 1-13. https://doi.org/10.1080/09589236.2017.1329715.

Eslen-Ziya, H., \& Koc, Y. (2016). Being A Gay Man in Turkey: Internalised Sexual Prejudice as a Function of Prevalent Hegemonic Masculinity Perceptions. Culture, Health \& Sexuality, 18(7), 799-811. https://doi.org/10.1080/13691058.2015.1133846.

Gabriel, Y., \& Ulus, E. (2015). “It's All in the Plot”: Narrative Explorations of Work-Related Emotions. In H. Flam \& J. Kleres (Ed.), Methods of Exploring Emotions (p. 36-45). Routledge.

Gorman-Murray, A. (2006a). Gay and Lesbian Couples at Home: Identity Work in Domestic Space. Home Cultures, 3(2), 145-167. https://doi.org/10.2752/174063106778053200.

Gorman-Murray, A. (2006b). Homeboys: Uses of Home by Gay Australian Men. Social \& Cultural Geography, 7(1), 53-69. https://doi.org/10.1080/14649360500452988.

Gorman-Murray, A. (2007). Contesting Domestic Ideals: Queering the Australian Home. Australian Geographer, 38(2), 195-213. https://doi.org/10.1080/00049180701392766.

Gorman-Murray, A. (2008). Queering the Family Home: Narratives from Gay, Lesbian and Bisexual Youth Coming Out in Supportive Family Homes in Australia. Gender, Place \& Culture, 15(1), 31-44. https://doi.org/10.1080/09663690701817501.

Green, A. I. (2008). Erotic Habitus: Toward a Sociology of Desire. Theory and Society, 37(6), 597-626. https://doi.org/10.1007/s11186-007-9059-4.

Güney, M. E., \& Selçuk, İ. A. (2016). LGBTTs of Turkey between the East and the West - The City and The World through Their Eyes in the Case of Izmir. Gender, Place \& Culture, 23(10), 1392-1403. https://doi.org/10.1080/0966369X.2016.1160870.

Held, N. (2015). Comfortable and Safe Spaces? Gender, Sexuality and "Race" in Night-Time Leisure Spaces. Emotion, Space and Society, 14, 33-42. https://doi.org/10.1016/j.emospa.2014.12.003.

Holliday, R. (1999). The Comfort of Identity. Sexualities, 2(4), 475-491.

Johnston, L., \& Valentine, G. (1995). Wherever I Lay My Girlfriend, that's My Home: The Performance and Surveillance of Lesbian Identities in Domestic Environments. In D. Bell \& G. Valentine (Ed.), Mapping Desire: Geographies of Sexualities (p. 99-113). Routledge.

$\mathrm{SAD} / \mathrm{JSR}$

Cilt / Volume 24 Say1 / Number 2 
Kentlyn, S. (2008). The Radically Subversive Space of the Queer Home: 'Safety House' and 'Neighbourhood Watch'. Australian Geographer, 39(3), 327-337. https://doi.org/10.1080/00049180802270523.

Korkut, U., \& Eslen-Ziya, H. (2016). The Discursive Governance of Population Politics: The Evolution of a Pro-Birth Regime in Turkey. Social Politics: International Studies in Gender, State \& Society, 23(4), 555-575. https://doi.org/10.1093/sp/jxw003.

McNay, L. (2008). Against Recognition. Polity Press.

Misgav, C., \& Johnston, L. (2014). Dirty Dancing: The (Non)Fluid Embodied Geographies of a Queer Nightclub in Tel Aviv. Social \& Cultural Geography, 15(7), 730-746. https://doi.org/10.1080/14649365.2014.916744.

Ozyegin, G. (2012). Reading the Closet through Connectivity. Social Identities, 18(2), 201-222. https://doi.org/10.1080/13504630.2012.652845.

Podmore, J. (2001). Lesbians in the Crowd: Gender, Sexuality and Visibility along Montreal's Boul. StLaurent. Gender, Place \& Culture, 8(4), 333-355. https://doi.org/10.1080/09663690120111591.

Reay, D. (2004). 'It's All Becoming A Habitus': Beyond the Habitual Use of Habitus in Educational Research. British Journal of Sociology of Education, 25(4), 431-444. https://doi.org/10.1080/0142569042000236934.

Seidman, S., Meeks, C., \& Traschen, F. (1999). Beyond the Closet? The Changing Social Meaning of Homosexuality in the United States. Sexualities, 2(1), 9-34. https://doi.org/10.1177/136346099002001002.

Sümer, S., \& Eslen-Ziya, H. (2017). New Waves for Old Rights? Womens Mobilization and Bodily Rights in Turkey and Norway. European Journal of Women's Studies, 24(1), 23-38. https://doi.org/10.1177/1350506815619878.

Taylor, Y., \& Falconer, E. (2015). 'Seedy Bars and Grotty Pints': Close Encounters in Queer Leisure Spaces. Social \& Cultural Geography, 16(1), 43-57. https://doi.org/10.1080/14649365.2014.939708. 
Ural, H., \& Beşpınar, F. U. (2017). Class and Habitus in the Formation of Gay Identities, Masculinities, and Respectability in Turkey. Journal of Middle East Women's Studies, 13(2), 244-264. https://doi.org/10.1215/15525864-3861323.

Valentine, G., Skelton, T., \& Butler, R. (2003). Coming Out and Outcomes: Negotiating Lesbian and Gay Identities with, and in, the Family. Environment and Planning D: Society and Space, 21(4), 479499. https://doi.org/10.1068/d277t.

Wetherell, M. (2012). Affect and Emotion: A New Social Science Understanding. Sage.

Wetherell, M. (2013). Affect and Discourse - What's the Problem? From Affect as Excess to Affective/Discursive Practice. Subjectivity, 6(4), 349-368. https://doi.org/10.1057/sub.2013.13.

Wimark, T. (2016). The Impact of Family Ties on the Mobility Decisions of Gay Men and Lesbians. Gender Place and Culture, 23(5), 659-676. https://doi.org/10.1080/0966369X.2015.1034246.

Y1lmaz, V., \& Göçmen, İ. (2016). Denied Citizens of Turkey: Experiences of Discrimination Among LGBT Individuals in Employment, Housing and Health Care. Gender, Work and Organization, 23(5), 470-488. https://doi.org/10.1111/gwao.12122.

Young, I. M. (2005). On Female Body Experience: "Throwing Like a Girl” and Other Essays. Oxford University Press. 